Available online at GSC Online Press Directory

GSC Biological and Pharmaceutical Sciences

e-ISSN: 2581-3250, CODEN (USA): GBPSC2

Journal homepage: https://www.gsconlinepress.com/journals/gscbps

(RESEARCH ARTICLE)

\title{
Medicinal plants used in the public health system of Abaetetuba, in the Brazilian Amazon
}

\author{
Fabiana Bittencourt Lima, Jeferson Miranda Costa and Dyana Joy dos Santos-Fonseca * \\ Laboratory of Biodiversity and Conservation, Federal Institute of Pará, IFPA, Abaetetuba, Pará, Brazil.
}

Publication history: Received on 12 June 2020; revised on 21 June 2020; accepted on 03 July 2020

Article DOI: https://doi.org/10.30574/gscbps.2020.12.1.0178

\begin{abstract}
We investigated the medicinal plants used by patients frequenting the public health system of Abaetetuba, in Pará State, in the Brazilian Amazon, and analyzed their socio-economic profile, recorded the habits and origins of those plant species, and conferred which are cited in the National List of Medicinal Plants of Interest to the Unified Health System (acronym - RENISUS). A total of 1089 questionnaires were applied during interviews held by 40 community health workers. The Flora do Brasil 2020 website was consulted to identify the habits and origins of the medicinal species. The Unified Health System of the Ministry of Health website was consulted to confirm the inclusion of those species of interest. Most users of medicinal plants were between 21 and 30 years of age (13\%), and were predominantly women $(60.23 \%)$ employed as maids. Forty-one species of medicinal plants were identified; the plants most familiar to users were "boldo" [Vernonia condensate Baker.], "cidreira" [Lippia alba (Mill.) N.E. Br.], "jucá" (Caesalpinia ferrea Mart), "hortelã" (Mentha sp.), "limão" [Citrus limon (L.) Burm.], "sicurijú" (Mikania lindleyana DC.), "barbatimão" (Stryphnodendron barbatimam Mart.), "marupazinho" [Eleutherine bulbosa (Mill.)], "anador" or "sete dores" (Plectranthus barbatus Andrews), and "erva doce" (Pimpinella anisum L.). Vernonia condensata is considered a plant of interest to the Brazilian health system, and represents the principal focus of this research.
\end{abstract}

Keywords: Ethnobotany; Public health; Phytopharmaceuticals; Folk medicine

\section{Introduction}

The Amazon region is rich in biological and cultural diversity, and its natural resources are widely used by local human populations [1]. Medicinal plants are one of the principal means of treating diseases there, especially in light of the high costs of commercial medicines [2].

The Brazilian National Policy for Medicinal and Herbal Plants and the National Policy for Integrative and Complementary Practices was created in 2006 to enrich discussions concerning opportunities their use, and the importance, advantages, and effectiveness of phytotherapies the public health system, as well as the difficulties their incorporation face [3].

Community health workers represent the first line of health teams in contact with local residents through home visits. The relationships of those professionals with their communities is of paramount importance, as they occupy the space in which the therapeutic uses of medicinal plants are discussed [4].

Several projects carried out in Abaetetuba have shown interest in studying the medicinal plants used by different communities there (including riverine communities [5] and remnants of traditional black settlements - "quilombos") [6] [7]. The species cultivated in home gardens have also been researched [8] [9] [10], as well as herbal practices in

\footnotetext{
* Corresponding author: Dyana Joy dos Santos-Fonseca; e-mail: dyanajoybio@gmail.com
} 
urban areas [11]. The city presents itself as a promising source of ethnobotanical knowledge, especially as concerns the fields of public health and popular medicine.

The present study investigated the medicinal plants known and used by patients registered with the public health system of Abaetetuba, and also analyzed the socio-economic profiles of the informants; verified the habits and origins of the plant species they used, cross-referenced them with those cited in the National List of Medicinal Plants of Interest to the Unified Health System (Brazilian acronym - RENISUS), as well as listed relevant aspects of the importance of their uses - thus presenting a systematization of local folk knowledge that can contribute to the documentation and enhancement of popular medicinal practices.

\section{Material and methods}

\subsection{Study area}

The municipality of Abaetetuba in Pará State, is situated in the Brazilian Amazon, and covers $1,611 \mathrm{~km}^{2}$ with approximately 140,000 inhabitants [12]. The vegetation there is typically Amazonian, but also now largely composed of secondary forests interspersed with agricultural areas [12]. The hydrographic network in the municipality is quite vast, with several large rivers [13].

The city is divided into an urban area with 16 neighborhoods, and a rural area comprising 20 islands and 49 locations (the latter mostly along roads, with fewer located in transition areas between the roads and the islands) [14].

The municipality has 54 public health posts, which were established according to local needs [14] The present study investigated three health posts in the urban area of Abaetetuba, and one in a rural site (Figure 1).

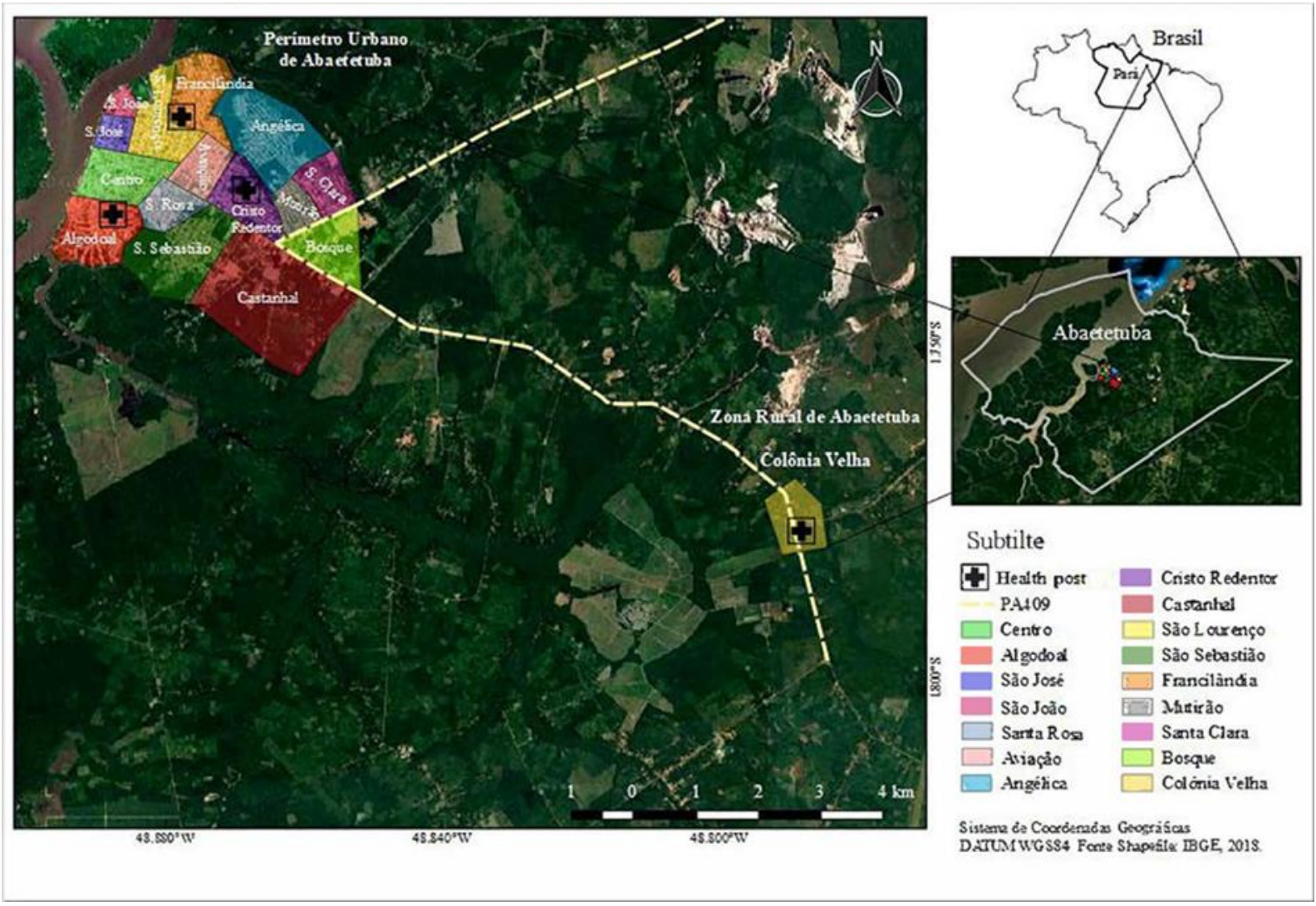

Figure 1 Locations of the Health Services investigated.

\subsection{Ethical procedures}

This research was registered on the Platform of the National System for the Management of Genetic Heritage and Associated Traditional Knowledge (Brazilian acronym - SisGen) under registration number A1C6307. 


\subsection{Collection and analysis of ethnobotanical data}

We examined 1089 questionnaires that had been applied by 40 community health agents among the local population, analyzed the socioeconomic profiles of citizens registered in the public health system, and determined which medicinal plants were used by them. The most representative botanical families were quantified in terms of their numbers of species. The most cited plants represent the "cultural salience" among informants, based on the free-listing method [15]. We selected ten of the most cited species to conduct a literature search. The Flora do Brasil 2020 site [Flora do Brasil 2020, under construction. Jardim Botânico do Rio de Janeiro, http://floradobrasil.jbrj.gov.br/., accessed on: 15 jun. 2019] was consulted to identify the habits and origins of the species. The criteria used were: Exotic - species not native to the Amazon phytogeographic domain; and, Native - native species. To determine if the species are of interest to the Brazilian public health system, we consulted the Ministry of Health website [http://bvsms.saude.gov.br/bvs/sus/pdf/marco/ms_relacao_plantas_medicinais_sus_0603.pdf., accessed on: 15 jun. 2019].

Visits were made to the neighborhoods where the health posts were located. We used the snowball technique, followed by guided tours [15]. After collection, the plant material was herborized according to standard techniques [16].

The popular names cited in the questionnaires were investigated and identified by herbarium searches. The collected plants were identified by consulting the specialized literature on medicinal plants [1]. Botanical families were circumscribed according to the 2016 classification system of the Angiosperm Phylogeny Group.

\section{Results and discussion}

The questionnaires revealed that 171 (15.7\%) informants used medicinal plants, while 150 (13.7\%) did not; 768 $(70.5 \%)$ health records contained incomplete information about the possible use of medicinal plants. The existence of health records with incomplete information reinforces the importance of professional training for community health workers. The performances of those professionals reflect on the principles of the Brazilian public health system, which are essential for an effective and adequate understanding of the system [17].

The citizens with health records registered in the public health system, and who most resorted to the use of medicinal plants, were between 21 and 30 years-old, representing $13 \%$ of the sample, followed by the 31 to 40 -year-old age group (11.5\%).

Women were the most representative informants (103 participants, or $60.23 \%$ ), while men composed $39.76 \%$ of the sample (68 participants). People close to 30 years old were most willing to provide information about the use of medicinal plants, while younger people generally preferred commercial chemical remedies [18].

Women were most likely to use medicinal plants, as they are largely responsible for family health care [19].

Of the citizens registered in the public health system, 56.14\% (96 people) have only a primary level of education, followed by high school level 22.22\% (38 people), and higher education $2.92 \%$ (5); no information was available for $14.61 \%$ (25); the predominance of informants with only primary levels of education has likewise been reported in similar studies [20] [4], which reflects easy access to those treatments and their low costs [21].

A majority of the informants were housewives (as was also reported for the basic health units in Colombo in Paraná State, Brazil) [22], which reflects their traditional knowledge about natural medicines, and the roles of women within their families and society [23].

The users of medicinal plants (and who are registered in the public health system) reported the names of 41 plants distributed among 27 families. Thirty-seven plants were identified to the species level, three to the genus level ["hortelã" (Mentha sp.), "hortelãzinho" (Mentha sp.), and "verônica" (Dalbergia sp.)], and one only to the family level ("salva", Asteraceae). The families Asteraceae (06 spp.), Lamiaceae (05 spp.), Fabaceae (03 spp.), and Euphorbiaceae (03 spp.) were the most cited. Many of the medicinal species belonging to those representative families have been studied from chemical and pharmacological points of view, and are therefore of great interest to science [24] (Table 1). 
Table 1 Medicinal plants of the public health system in the city of Abaetetuba, Brazilian Amazon.

\begin{tabular}{|c|c|c|c|c|c|c|}
\hline $\begin{array}{l}\text { Popular } \\
\text { name }\end{array}$ & Scientific name & Family & Citation & Habit & Origin & RENISUS \\
\hline Abacaxi & Ananas comosus (L.) Merr. & Bromeliaceae & 1 & Herb & Native & Yes \\
\hline Alecrim & Rosmarinus officinalis L. & Lamiaceae & 3 & Herb & - & - \\
\hline $\begin{array}{l}\text { Amor } \\
\text { crescido }\end{array}$ & Portulaca pilosa L. & Portulacaceae & 3 & Herb & Native & Yes \\
\hline $\begin{array}{l}\text { Anador/ } \\
\text { Sete dores }\end{array}$ & Plectranthus barbatus Andrews & Lamiaceae & 7 & Herb & Exotic & Yes \\
\hline Aroeira & Schinus terebinthifolia Raddi & Anacardiaceae & 1 & Bush & Exotic & Yes \\
\hline Arruda & Ruta graveolens L. & Rutaceae & 2 & Herb & Exotic & Yes \\
\hline Babosa & Aloe vera (L.) Burm. & Xanthorrhoeaceae & 7 & Herb & Exotic & Yes \\
\hline Barbatimão & Stryphnodendron barbatimam Mart. & Fabaceae & 11 & Tree & Exotic & Yes \\
\hline Boldo & Vernonia condensate Baker. & Asteraceae & 93 & Bush & Exotic & - \\
\hline Camomila & Matricaria recutita $\mathrm{L}$ & Asteraceae & 2 & Herb & Exotic & Yes \\
\hline $\begin{array}{l}\text { Canafiche/ } \\
\text { Canarana }\end{array}$ & Costus arabicus L. & Costaceae & 3 & Bush & Native & Yes \\
\hline Canela & Cinnamomum verum J. Persl & Lauraceae & 6 & Tree & Exotic & - \\
\hline Capim santo & Cymbopogon citratus (DC.) Stapf. & Poaceae & 4 & Herb & - & - \\
\hline Mamorana & Pachira insignis (Sw.) Sw. ex Savigny & Malvaceae & 1 & Tree & Native & - \\
\hline Caxingubam & Ficus insipida Willd. & Moraceae & 1 & Bush & Native & - \\
\hline Coramina & Pedilanthus tithymaloides (L.) Poit. & Euphorbiaceae & 3 & Bush & - & - \\
\hline Cravo & Tagetes erecta $\mathrm{L}$. & Asteraceae & 2 & Herb & Native & - \\
\hline Erva cidreira & Lippia alba (Mill.) N.E. Br. & Verbenaceae & 42 & Bush & Native & - \\
\hline Erva doce & Pimpinella anisum L. & Apiaceae & 9 & Herb & - & - \\
\hline Eucalipto & Eucalyptus globulus Labill. & Myrtaceae & 1 & Tree & - & Yes \\
\hline Gengibre & Zingiber officinale Roscoe & Zingiberaceae & 1 & Herb & Exotic & Yes \\
\hline Hortelã & Mentha sp. & Lamiaceae & 15 & Herb & - & Yes \\
\hline Hortelazinho & Mentha sp. & Lamiaceae & 3 & Herb & - & Yes \\
\hline Jucá & Caesalpinia ferrea Mart & Fabaceae & 24 & Tree & - & - \\
\hline Limão & Citrus limon (L.) Burm. & Rutaceae & 14 & Bush & - & - \\
\hline Marcela & Pluchea sagittalis (Lam) & Asteraceae & 2 & Herb & - & - \\
\hline Marupazinho & Eleutherine bulbosa (Mill.) & Iridaceae & 11 & Herb & Native & - \\
\hline Mastruz & Chenopodium ambrosioides L. & Amaranthaceae & 5 & Herb & - & Yes \\
\hline Noni & Morinda triphylla (Ducke) Steyerm. & Rubiaceae & 5 & Tree & Native & - \\
\hline Óleo Elétrico & Piper callosum Ruiz \& Pav. & Piperaceae & 5 & Bush & Native & - \\
\hline Oriza & Pogostemom heyneanus Benth. & Lamiaceae & 3 & Herb & - & - \\
\hline Pariri & Fridericia chica L.G.Lohmann & Bignoniaceae & 4 & Bush & Native & - \\
\hline Peão roxo & Jatropha gossypiifolia L. & Euphorbiaceae & 1 & Bush & Native & Yes \\
\hline Pirarucu & kalanchoe pinnata (Lam.) Pers & Crassulaceae & 5 & Herb & Native & Yes \\
\hline Quebra-pedra & Phyllantthus ninuri L. & Phyllanthaceae & 7 & Herb & - & Yes \\
\hline
\end{tabular}


Lima et al. / GSC Biological and Pharmaceutical Sciences, 2020, 12(01), 080-086

\begin{tabular}{|c|c|c|c|c|c|c|c|}
\hline Sacaca & Croton cajura Beth & & Euphorbiaceae & 1 & Bush & - & - \\
\hline Salva & - & & Asteraceae & 1 & - & - & - \\
\hline Sicurijú & Mikania lindleyana DC. & & Asteraceae & 12 & Liana & - & - \\
\hline Sucuúbá & $\begin{array}{l}\text { Himatanthus articulatus } \\
\text { Woodson }\end{array}$ & (Vahl) & Apocynaceae & 2 & Tree & Native & \\
\hline Vassorinha & Scoparia dulcis L. & & Plantaginaceae & 1 & Herb & Native & - \\
\hline Verônica & Dalbergia sp. & & Fabaceae & 3 & Liana & Native & - \\
\hline
\end{tabular}

The ten species with the greatest cultural salience among the people registered in the public health system were: "boldo" [Vernonia condensate Baker.], "cidreira" [Lippia alba (Mill.) N.E. Br.], "jucá" (Caesalpinia ferrea Mart), "hortelã" (Mentha sp.), "limão" [Citrus limon (L.) Burm.], "sicurijú" (Mikania lindleyana DC.), "barbatimão" (Stryphnodendron barbatimam Mart.), "marupazinho" [Eleutherine bulbosa (Mill.)], "anador" or "sete dores" (Plectranthus barbatus Andrews), and "erva doce" (Pimpinella anisum L.), see Table 2.

The most-cited herbs were: "hortelã" (Mentha sp.), "marupazinho" [Eleutherine bulbosa (Mill.)], "anador" or "sete dores" (Plectranthus barbatus Andrews), "erva doce" (Pimpinella anisum L.), and "quebra-pedra" (Phyllantthus ninuri L.). The predominance of herbs may be related to the fact that plants of that habit are easier to cultivate, which helps ensure their availability [25].

The medicinal species whose origins could be determined including 16 species native to the Amazon, while nine are exotic to the region. The flora of the Brazilian Amazon offers an appreciable medicinal potential due to its large number of native and exotic plants [1]. Native plants from the Amazon reflect a strong endemic trait in the herbal medicine of Abaetetuba [7], while the use of exotic species in the plant pharmacopoeia of northern South America reflects a European cultural heritage in the colonization of the region [26].

Seventeen (17) of the species used in Abaetetuba were also encountered in the list of plants of interest to the Brazilian public health system. We emphasize Vernonia condensata (boldo) as the most-cited species and as a species listed in the health system- indicating it as a promising source of antioxidants [28].

Table 2 Use of medicinal plants in the public health system.

\begin{tabular}{llll}
\hline Popular name & Medicinal Properties & Citations & \% \\
\hline Boldo & Assists in the treatment of liver and stomach diseases [27] & 93 & 38,58 \\
Cidreira & $\begin{array}{l}\text { Naturally soothing, with mild analgesic and antispasmodic } \\
\text { properties [3] [27] }\end{array}$ & 42 & 17,42 \\
Jucá & Wound healing, and acts as an anti-inflammatory [11] & 24 & 9,95 \\
Hortelã & Used in liver ailments and respiratory disorders [3] & 15 & 6,22 \\
Limão & $\begin{array}{l}\text { Natural diuretic, antiscorbutic, with anti-rheumatic, } \\
\text { astringent, with antiseptic action [27] }\end{array}$ & 5,80 \\
Sicurijú & $\begin{array}{l}\text { Anti-inflammatory and healing. Used in liver treatments, } \\
\text { chronic and varicose ulcers [1] }\end{array}$ & 4,97 \\
Barbatimão & $\begin{array}{l}\text { Treat uterine bleeding, vaginal discharge, healing, and anti- } \\
\text { inflammatory [1] [3] [27] }\end{array}$ & 41 \\
Marupazinho & $\begin{array}{l}\text { Treatment of diarrhea and worm elimination [27] } \\
\text { Anador/ sete dores }\end{array}$ & $\begin{array}{l}\text { Treats liver disorders and aids digestion. Also used to treat } \\
\text { gastritis, gastric ulcers, and headaches [3] [27] }\end{array}$ & 11 \\
Erva doce & $\begin{array}{l}\text { Stimulates digestive functions, helps eliminate gas and fight } \\
\text { colic, also treats headaches [27] }\end{array}$ & 9 & 4,56 \\
& & 241 & 3,14 \\
\hline
\end{tabular}




\section{Conclusion}

It will be necessary to improve the training of the health professionals responsible for filling out the registration documents of the public health system. Young and adult women with elementary school educations, together with housewives, are the people who most reported the use of medicinal plants. Herbs compose a large percentage of the native Amazon species used in popular medicine, although exotic species are also frequently sought after and used. The medicinal species mentioned in the records of the public health system in Abaetetuba can also be found in the National List of Medicinal Plants of Interest to the Unified Health System. Vernonia condensata is considered a plant of interest to the Brazilian health system, being identified here as the principal specie listed and used in Abaetetuba.

\section{Compliance with ethical standards}

\section{Acknowledgments}

The authors thank the Federal Institute of Pará Herbarium (HIFPA) for access to their collection of medicinal plants from Baixo Tocantins, in the Brazilian Amazon, and the Professor Natanael Charles da Silva for previously evaluating this article.

\section{Disclosure of conflict of interest}

All authors declare no conflict of interest.

\section{References}

[1] Berg MEVD. (2010). Plantas medicinais na Amazônia: contribuição ao seu conhecimento sistemático. Museu Paraense Emílio Goeldi, Belém, PA, 268.

[2] Elisabetsky E and Wannamacher L. (1993). The Status of Ethnopharmacology in Brazil. Journal of Ethnopharmacology, 38, 137-143.

[3] Saad GA, Léda PHO, Sá IM and Seixlack ACC. (2009). Fitoterapia Contemporânea Tradição e Ciência na Prática Clínica. Elsevier, Rio de Janeiro, RJ, 274.

[4] Galavote HS, Prado TN, Maciel ELN and Lima RCD. (2011). Desvendando os processos de trabalho do agente comunitário de saúde nos cenários revelados na Estratégia Saúde da Família no município de Vitória (ES, Brasil). Ciência \& Saúde Coletiva, 16(1), 231-240.

[5] Moura PHM, Lucas FCA, Tavares-Martins ACC, Lobato GJM and Gurgel ESC. (2016). Etnobotânica de chás terapêuticos em Rio Urubueua de Fátima, Abaetetuba - Pará, Brasil. Biotemas, 29(2), 77-88.

[6] Gonçalves JP and Lucas FCA. (2017). Agrobiodiversidade e etnoconhecimento em quintais de Abaetetuba, Pará, Brasil. Revista Brasileira de Biociências, Porto Alegre, 15(3), 119-134.

[7] Pereira MGS and Coelho-Ferreira M. (2017). Uso e diversidade de plantas medicinais em uma comunidade quilombola na Amazônia Oriental, Abaetetuba, Pará. BIOTA, 7(3), 57-68.

[8] Ferreira LB, Rodrigues MO and Costa JM. (2016). Etnobotânica das Plantas Medicinais Cultivadas nos Quintais do Bairro de Algodoal em Abaetetuba/PA. Revista Fitos, 10(3), 220-374.

[9] Miranda TG, Oliveira-Júnior JF, Martins-Júnior AS and Tavares-Martins ACC. (2016). 0 uso de plantas em quintais urbanos no bairro da Francilândia no município de Abaetetuba, Pará, Brasil. Scientia Plena, 12(6), 3-18.

[10] Palheta IC, Martins ACCT, LUCAS FCA and Jardim MAG. (2017). Ethnobotanical study of medicinal plants in urban home gardens in the city of Abaetetuba, Pará state, Brazil. Boletín Latinoamericano y del Caribe de Plantas Medicinales y Aromáticas, 16(3), 206-262.

[11] Flor ASSO, Flor RSJ and Ribeiro I. (2015). Fitoterapia Solidária: remédios caseiros produzidos no centro médico Nossa Senhora da Conceição Abaetetuba-PA-Brasil. Cultivando o Saber, 15(1), 1-15.

[12] Secretaria de Estado de Planejamento, Orçamento e Finanças (SEPOF). Estatística municipal de Abaetetuba. 2011.

[13] Machado J. (2008). O município de Abaetetuba. Edições Alquimia, Abaetetuba, PA, 30.

[14] Secretaria Municipal de Meio Ambiente de Abaetetuba (SEMEA). Plano municipal de meio ambiente. 
[15] Albuquerque UP, Lucena RFP and Cunha LVFC. (2010). Métodos e técnicas na pesquisa etnobiológica e etnoecológica. NUPPEA, Recife, PE, 189.

[16] Stasi LC. (1996). Plantas medicinais: arte e ciência - um guia de estudo interdisciplinar. UNESP, São Paulo, SP. 230.

[17] Colet CF, Cavalheiro CAN, Molin GTD, Gavinnato AW, Schiavo M, Schwamcach KH and Oleiveira KR. (2015). Uso de plantas medicinais por usuários do serviço público de saúde do município de Ijuí-RS. Revista brasileira de medicina de família e comunidade, 10(36), 1-13.

[18] Lima CB. (2000). Plantas medicinais utilizadas em duas localidades do município de Bandeirantes-PR. Tese. Universidade Estadual Paulista, Brasil, 70.

[19] Badke MR, Budó MLD, Silva FM and Ressel LB. (2011). Plantas medicinais: o saber sustentado na prática do cotidiano popular na escola Anna Nery. Revista da Enfermagem, 15(1), 132-139.

[20] Ruas ELA, Martins PM, Escalda PMF and Silveira D. (2013). Estudo observacional do perfil do usuário de plantas medicinais que utilizam centros de saúde de Ceilândia, Distrito Federal. BioFar, 9(4), 1-8.

[21] Flor ASSO and Barbosa WLR. (2015). Sabedoria popular no uso de Plantas Medicinais pelos moradores do bairro do distrito de Marudá - PA. Revista Brasileira de Plantas Medicinais, 17(4), 757-768.

[22] Oliveira VB, Mezzomo TR and Moraes EF. (2018). Conhecimento e Uso de Plantas Medicinais por Usuários de Unidades Básicas de Saúde naRegião de Colombo. Revista Brasileira de Ciências da Saúde, 22(1), 57-64.

[23] Scoles R. (2016). Sabiduria popular y plantas medicinales: elejemplo de lacomunidad negra de Itacoã, Acará, Pará. Boletim do Museu Paraense Emílio Goeldi. Ciências Naturais, 1(2), 79-102.

[24] Di Stasi LC and Hiruma-Lima CA. (2002). Plantas medicinais na Amazônia e na Mata Atlântica. UNESP, São Paulo, 230 .

[25] Guarim-Neto G and Amaral CN. (2010). Aspectos etnobotânicos de quintais tradicionais dos moradores de Rosário Oeste, Mato Grosso, Brasil. Polibotánica, 29(1), 191-212.

[26] Bennett BC and Prance GT. (2000). Introduced plants in the indigenous pharmacopoeia of Northern South America. Economic Botany, 54(1), 90-102.

[27] Lorenzi H and Matos FJA. (2008). Plantas medicinais no Brasil: nativas e exóticas. Instituto Plantarum, Nova Odessa, 576.

[28] Silva J B, Temponi VS, Gapareto CM, Fabri RL, Aragão DMO, Pinto NCC, Ribeiro A, Scio E, Vieira GV, Sousa AOV and Alves MS. (2013). Vernonia condensata Baker (Asteraceae): A Promising Source of Antioxidants. Oxidative Medicine and Cellular Longevity, 13(1), 1-10.

\section{How to cite this article}

Lima FB, Costa JM and Santos-Fonseca DJ. (2020). Medicinal plants used in the public health system of Abaetetuba, in the Brazilian Amazon. GSC Biological and Pharmaceutical Sciences, 12(1), 80-86. 